\title{
Influence of technogenic contamination with heavy metals on structural state of typical chernozem
}

Riabchenko V.

NSC "O.N. Sokolovskyi Institute of soil science and agrochemistry», Chaikovska Str., 4, Kharkiv, 61024, Ukraine; e-mail: amsterdam.vova@gmail.com

The purpose. To determine structural and aggregate composition of chernozem and its changes under the influence of technogenic contamination. Methods. Field, analytical, statistical. Results. Results of probes $(2015-2017)$ on structural and aggregate composition of technogenically contaminated soil are brought. The amount of each fraction is determined and regularities of their allocation in soil profile are fixed. Conclusions. Regularities of change and allocation of amount of aggregates in different soil fractions under the influence of technogenic contamination are fixed.

Key words: technogenic contamination, heavy metals, structural and aggregate composition, typical chernozem, Open Society "Ukrzink", agronomically valuable aggregates, arable land.

Introduction. The study of soil structure due to its exceptional importance for creating a favorable water-air regime, efficient use of nutrients and a number of other important crop causes is extremely important. The technogenic contamination of soil by heavy metals, significantly changes and worsens structure-aggregates composition and that's why are important to study the structural-aggregate composition of soils that are contaminated [1-3]. Fateyev A. I., Miroshnichenko M. M., Byndych T. Yu and others researchers are found that as a result of anthropogenic soil contamination are deterioration and change in it physical properties in particular granulometric and structural-aggregate composition [4-6], that in turn leads to a deterioration of quality in yields and the ingress of heavy metals to the human organism [7-8]. Baydina N. L. are investigated the content of heavy metals in granulometric fractions of soil in the city Novosibirsk. She was found that about $40 \%$ of total number of the heavy metals are contained in finely dispersed particles $(<0.01 \mathrm{~mm})$ [9]. Byndych T. Yu. was determined the effect of multicomponent pollution on physical properties of soil. Zhuravleva I. M. and Fateyev A.I. was concluded that soil contamination with heavy metals leads to the destruction of soil aggregates and the dispersion of the soil $[4,6,10]$.

Object. The structural-aggregate composition of ordinary chernozems and identify its changes under the influence of technogenic pollution was determine.

Material and methods of research. The studies were conducted in 2015-2017 gg. at the technogenic contaminated ordinary chernozem by "Ukrtsynk" at the city Kostiantynivka of Donetsk region. Soil samples were taken in the summer period in two repetitions from each monitoring site - directly near the object of pollution and at a distance of 3-5 km from it (Fig. 1). Samples were taken from the depth of the soil profile $0-10 \mathrm{~cm}, 10-20 \mathrm{~cm}$ and $20-40 \mathrm{~cm}$, that is, from the arable and sub-soils layers of soil. 


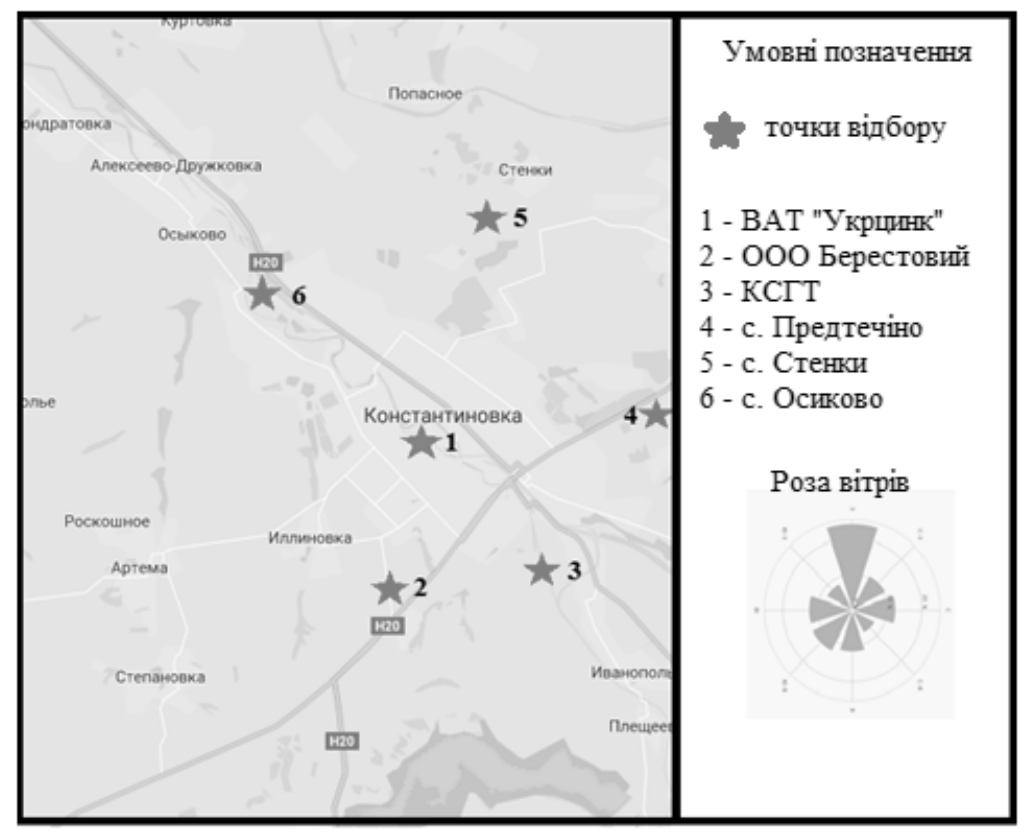

Fig. 1 - Places of sampling of black earth of ordinary heavy-bodied

Field and analytical studies were carried out according to standardized methods: soil samples were taken in accordance with the standard DSTU ISO 10381-2: 2004, the determination of the structuralaggregate composition was determined by the sieve method in the modification of N. I. Savvinov DSTU 4744: 2007 . The statistical processing of the obtained research results was carried out using the program package «Statistica 8» and MS Excel.

Results of research. An increase in the number of aggregates in the smallest fractions $(<0.25 \mathrm{~mm})$ was noted, which is characteristic for technogenically polluted [6]. The number of aggregates in the smallest fractions $(<0.25 \mathrm{~mm})$ is increase. This is particularly evident at point 1 directly near the object of contamination. A slightly smaller number of this fraction is noted at points 5 and 6 , which is related to the direction of the prevailing winds and, as a result, to less intense contamination by heavy metals. At points 2-6 there is an increase in the number of bryllium fractions and a decrease in the number of agronomically valuable aggregates $(10-0.25 \mathrm{~mm})$ as a result of plowing.

The fraction content> $7 \mathrm{~mm}$ for all points $(30-50 \%)$, except for item 1, where it is $4 \%$ of the total content. A similar trend is observed for other fractions, except $0.5-0.25 \mathrm{~mm}$ and $<0.25 \mathrm{~mm}$. In the smallest two factions, the largest number of aggregates was observed at the point 1 - about $16 \%$.

Some redistribution of fractions is noted with depth. So the quantity of aggregates $>2 \mathrm{~mm}$ increases with depth at all points of selection, except for point 6 , where the number of aggregates are decrease. In fractions $<2 \mathrm{~mm}$, the number of aggregates is reduced for all types of use, except for the fraction $<0.25$ $\mathrm{mm}$ at the selection point 1 , where is observed its increase with depth .

Table 1. Structural composition of chernozem commonly technically contaminated by «Ukrzink» (for dry and wet sifting)

\begin{tabular}{|c|c|c|c|c|c|c|c|c|}
\hline \multirow{2}{*}{ Objects } & \multirow{2}{*}{$\begin{array}{l}\text { Depth } \\
\text { sm }\end{array}$} & \multicolumn{7}{|c|}{ Number of aggregates in dry / wet shedding, $\% / \mathrm{mm}$} \\
\hline & & $>7$ & $7-5$ & $5-2$ & $2-1$ & $1-0,5$ & $0.5-0.25$ & $<0.25$ \\
\hline \multirow{3}{*}{$\begin{array}{l}\text { Point } 1 \text { - } \\
\text { Ukrzink }\end{array}$} & $0-10$ & $5,9 / 4,4$ & $2,2 / 1,8$ & $20,8 / 4,6$ & $30,1 / 23,6$ & $6,9 / 20,8$ & $17,7 / 13,4$ & $16,4 / 31,4$ \\
\hline & $10-20$ & $10,1 / 2,2$ & $4,1 / 4,2$ & $25,1 / 8,8$ & $21,8 / 16,8$ & $5,6 / 22,6$ & $16,1 / 10,2$ & $17,2 / 35,2$ \\
\hline & $20-40$ & $4,2 / 1,6$ & $6,2 / 6,6$ & $31,6 / 22,6$ & $20,1 / 24,8$ & $5,0 / 12,0$ & $11,5 / 8,2$ & $21,4 / 24,2$ \\
\hline \multirow{3}{*}{$\begin{array}{l}\text { Point } 2 \text { - } \\
\text { Berestovo } \\
\text { Ltd. }\end{array}$} & $0-10$ & $38,7 / 6,0$ & $9,6 / 9,4$ & $19,8 / 9,4$ & $15,3 / 20,6$ & $3,9 / 23,0$ & $7,9 / 12,6$ & $4,9 / 22,2$ \\
\hline & $10-20$ & $39,9 / 6,0$ & $\overline{10 / 9,4}$ & $22,3 / 9,4$ & $13,9 / 25,4$ & $3,4 / 20,4$ & $6,3 / 12,2$ & $4,3 / 20,8$ \\
\hline & $20-40$ & $40,6 / 6,0$ & $12,2 / 11,2$ & $25,1 / 11,2$ & $10,9 / 21,6$ & $2,6 / 17,6$ & $4,8 / 12,0$ & $3,8 / 26,6$ \\
\hline \multirow{3}{*}{$\begin{array}{l}\text { Point } 3 \text { - } \\
\text { KSGT }\end{array}$} & $0-10$ & $28,6 / 28,2$ & $14,9 / 16,6$ & $31,4 / 16,6$ & $13,4 / 13,4$ & $2,8 / 8,4$ & $5,6 / 5,8$ & $3,4 / 16,6$ \\
\hline & $10-20$ & $52,3 / 42,6$ & $14,0 / 15,0$ & $22,4 / 15,0$ & $6,1 / 9,0$ & $1,2 / 5,2$ & $1,9 / 3,2$ & $2,2 / 12,8$ \\
\hline & $20-40$ & $50,9 / 18,2$ & $11,4 / 12,4$ & $21,9 / 18,0$ & $7,2 / 19,0$ & $1,5 / 9,4$ & $3,0 / 5,8$ & $4,2 / 17,2$ \\
\hline
\end{tabular}




\begin{tabular}{|c|c|c|c|c|c|c|c|c|}
\multirow{4}{*}{$\begin{array}{c}\text { Point 4 } \\
\text { Predecino }\end{array}$} & $0-10$ & $33,9 / 33,4$ & $12,2 / 11,6$ & $29,9 / 11,6$ & $13,0 / 18,8$ & $2,7 / 9,8$ & $5,2 / 6,2$ & $3,2 / 13,0$ \\
\cline { 2 - 9 } & $10-20$ & $36,5 / 29,0$ & $19,5 / 17,0$ & $27,5 / 17,0$ & $9,4 / 15,6$ & $1,7 / 7,0$ & $3,2 / 4,4$ & $2,2 / 10,4$ \\
\cline { 2 - 9 } & $20-40$ & $32,4 / 12,8$ & $15,9 / 27,0$ & $30,1 / 27,0$ & $11,8 / 15,2$ & $2,3 / 6,4$ & $4,5 / 3,8$ & $2,9 / 9,6$ \\
\hline \multirow{2}{*}{$\begin{array}{c}\text { Point 5 - } \\
\text { Stenki }\end{array}$} & $0-10$ & $37,6 / 5,8$ & $4,7 / 6,8$ & $12.0 / 6,8$ & $18,4 / 15,8$ & $5,3 / 24,6$ & $13,1 / 16,0$ & $9,0 / 25,6$ \\
\cline { 2 - 9 } & $10-20$ & $42,0 / 4,0$ & $6,3 / 7,6$ & $14,4 / 7,6$ & $15,5 / 18,4$ & $3,4 / 17,2$ & $9,7 / 11,4$ & $8,7 / 33,6$ \\
\cline { 2 - 9 } & $20-40$ & $38,5 / 6,8$ & $9,6 / 14,8$ & $22,5 / 14,8$ & $13,4 / 20,4$ & $3,7 / 16,0$ & $6,5 / 8,8$ & $5,7 / 23,8$ \\
\hline \multirow{2}{*}{$\begin{array}{c}\text { Point 6 } \\
\text { Osikovo }\end{array}$} & $0-10$ & $32,5 / 6,6$ & $6,2 / 7,2$ & $19,0 / 7,2$ & $14,8 / 29,6$ & $5,8 / 28,8$ & $11,8 / 9,8$ & $9,9 / 15,8$ \\
\cline { 2 - 9 } & $10-20$ & $37,4 / 1,8$ & $8,7 / 15,8$ & $22,7 / 15,8$ & $14,8 / 18,2$ & $4,1 / 19,4$ & $7,5 / 12,2$ & $4,8 / 24,0$ \\
\cline { 2 - 9 } & $20-40$ & $21,9 / 0,8$ & $14,8 / 20,0$ & $35,4 / 20,0$ & $14,8 / 29,2$ & $3,0 / 16,8$ & $5,9 / 10,2$ & $4,3 / 17,6$ \\
\hline \multirow{3}{*}{ NIR } & $0-10$ & $6,4 / 4,9$ & $5,1 / 3,4$ & $6,3 / 3,4$ & $4,1 / 5,7$ & $3,7 / 4,8$ & $2,1 / 4,2$ & $1,7 / 5,1$ \\
\cline { 2 - 9 } & $10-20$ & $7,1 / 5,0$ & $6,0 / 3,7$ & $6,9 / 3,7$ & $3,9 / 6,1$ & $4,0 / 5,7$ & $2,2 / 4,5$ & $2,0 / 6,0$ \\
\cline { 2 - 9 } & $20-40$ & $8,2 / 5,9$ & $8,7 / 4,1$ & $7,1 / 4,1$ & $4,3 / 6,3$ & $4,5 / 5,9$ & $2,9 / 4,9$ & $2,7 / 6,6$ \\
\hline
\end{tabular}

For all types of wet sieve analysis is observed a decrease in the number of aggregates $>7 \mathrm{~mm}$. The opposite situation is observed in fractions $7-5 \mathrm{~mm}, 5-2 \mathrm{~mm}$ and 2-1 $\mathrm{mm}$, where there is an increase in their number both in depth and in the total number. At points 3 and 5 there is a decrease in the number of smallest fractions $<0.5 \mathrm{~mm}$, in others, on the contrary, there is an increase in the number of aggregates. The largest number of aggregates in shallow fractions $(<0.5 \mathrm{~mm})$ is observed at points 1,2 and 5 .

The highest water resistance of the aggregates was found at the point 6 , somewhat worse at points 2 and 5 , and the smallest - at the point 3 . In all points, an increase in the number of water-resistant aggregates with a depth except point 2 , where it decreases, that is associated with a different degree of soil tillage and possibly the introduction of organic fertilizers.

\section{Conclusions}

It was established that as a result of technogenic pollution soils by heavy metals are increase their dusting (increasing the fraction> $0.25 \mathrm{~mm}$ ) and decreasing the number of agronomically valuable aggregates. It was investigated that pollution by heavy metals leads to deterioration of water resistance of soils and its structure in general.

\section{Bibliography}

1. Medvedev V.V. (2010). Standards for the formation and conservation of the soil structure. Bulletin Agricul . Science No. 3. P. 9-13. [In Ukrainian].

2. Medvedev V.V. (2008). Structure of soil (methods, genesis, classification, evolution, geography, monitoring , protection ). Kharkov: 13 printing-houses. 406 p. [In Russian].

3. Panasenko O.S. (2015). Humus of structural units of chernozems typical of natural and aerogenic ecosystems: Monograph. Ed. V.V. Dehtiarova. Kharkiv: Maidan 192 p. [In Ukrainian].

4. Bindych T. Yu. (2000). The regularities of changes of the basic soil processes under the influence of heavy metals : author's abstract. dis for the degree of Candidate of Sciences s.-g. sciences: 03.00.27. Kharkiv. 20 p. [In Ukrainian].

5. Miroshnichenko M.M., Fateev A.I. (2010). Agrochemistry of microelements in soils of Ukraine. Agrochemistry and soil science. Special issue to the 8th UTGA Congress. The book is first. P. 98-107. [In Ukrainian].

6. Fateev A.I. (2003). Background content of trace elements in soils of Ukraine. Ed. A.I. Fateyev,. Ya.V. Pashchenko. Kharkiv. 120 p. [In Ukrainian].

7. Madrid F., Biasioli M., Ajmone-Marsan F. (2008). Arch Environ Contam. Toxicol. 21-32 P.

8. Kothe E., Varma A. (2012). Bio-geo interactions in metal-contaminated soils. New York: Springer. P. 14-17.

9. Baidina N.L. (2000). Contents heavy metals in urbanareas soils and theirs granulometric factions. Geochemical ecology and biogeochemical study taxon of Biosphere: Materials 3rd Rus. biogeochem. sch. (Gorno-Altaisk, September 4-8, 2000). Novosibirsk. P. 87-88. [In Russian]. 
10. Zhuravleva I.M. (2015). Agrochemical aspects of the toxicity of heavy metals in the soil-plant system: author's abstract diss for the degree of Candidate of Sciences s.-g. Sciences : 06.01 .04 / I.M. Zhuravlev. Kharkiv. 24 p. [In Russian]. 